\title{
LANGKAH SUKSES MEMULAI USAHA
}

\author{
Oleh : Suwinardi \\ Staf Pengajar Jurusan Teknik Elektro Politeknik Negeri Semarang \\ Jl. Prof. Sudarto, SH, Tembalang, Semarang, 50275 \\ Email: suwinardi@polines.ac.id
}

\begin{abstract}
Abstrak
Pada dasarnya seseorang untuk menjadi wirausaha yang handal tidaklah mudah. Tetapi tidaklah sesulit yang dibayangkan banyak orang, karena sebenarnya berwirausaha dapat dipelajari oleh setiap orang. Kemauan dan kemampuan untuk mengambil risiko merupakan salah satu nilai utama dalam kewirausahaan. Wirausaha yang tidak mau mengambil risiko akan sukar memulai atau berinisiatif, namun tidak hanya itu saja. Memulai usaha merupakan suatu hal yang penting dalam melakukan usaha, oleh sebab itu memerlukan kiat yang tepat untuk memperoleh kesuksesan. Ada beberapa langkah-langkah yang dapat dilakukan apabila seseorang ingin memulai wirausaha, antara lain pilih bidang usaha yang Anda minati dan memiliki hasrat dan pengetahuan di dalamnya, perluas dan perbanyak jaringan bisnis dan pertemanan, pilihlah keunikan dan nilai unggul dalam produk/jasa anda, jaga kredibilitas dan brand image. Disamping itu dalam berwirausaha sangat diperlukan kejujuran dalam usahanya, karena akan membawa keberhasilan dan kesuksesan dari akibat kepercayaan pelanggan.
\end{abstract}

Kata kunci : Kewirausahaan, wirausaha

\section{Pendahuluan}

Kewirausahaan pada hakekatnya adalah sifat, ciri dan watak seseorang yang memiliki kemauan dalam mewujudkan gagasan inovatif ke dalam dunia nyata secara kreatif (Suryana, 2000). Istilah kewirausahaan berasal dari terjemahan "Entrepreneurship", dapat diartikan sebagai "the backbone of economy", yang adalah syaraf pusat perekonomian atau pengendali perekonomian suatu bangsa (Soeharto Wirakusumo, 1997:1). Secara epistimologi, kewirausahaan merupakan suatu nilai yang diperlukan untuk memulai suatu usaha atau suatu proses dalam mengerjakan sesuatu yang baru dan berbeda. Menurut Thomas W Zimmerer, kewirausahaan merupakan penerapan kreativitas dan keinovasian untuk memecahkan permasalahan dan upaya untuk memanfaatkan peluang yang dihadapi sehari-hari. Kewirausahaan merupakan gabungan dari kreativitas, keinovasian dan keberanian menghadapi resiko yang dilakukan dengan cara kerja keras untuk membentuk dan memelihara usaha baru.

Wirausaha adalah kemampuan yang dimiliki oleh seseorang untuk melihat dan menilai kesempatan-kesempatan bisnis; mengumpulkan sumber daya-sumber daya yang dibutuhkan untuk mengambil tindakan yang tepat dan mengambil keuntungan dalam rangka meraih sukses.

Wirausaha merupakan orang yang mengorganisir dan mengarahkan usaha baru. Wirausaha berani mengambil risiko yang terkait dengan proses memulai usahanya. Beberapa Wirausaha dapat terlahir dalam suatu seni dengan mulai membuka usaha kecil-kecilan seperti kedai nasi, kios rokok, bengkel sepeda, dan akhirnya terus berkembang menjadi besar dan sukses. Kebanyakan dari mereka yang belajar menjadi Wirausaha, selalu mengikuti dan mempelajari keberhasilan para Wirausaha yang berpengalaman. Mungkin mereka telah mengagumi keberhasilan seseorang, kerabat, kawan, atau dari orang tua.

Perkembangan kegiatan ekonomi terus tumbuh dan mengalami pasang surut. Kondisi ini menyebabkan setiap orang berusaha mengembangkan diri dengan kompetensi yang dimiliki untuk mengembangkan ide dan meraih peluang yang terukur dan tingkat prestasi tertentu pula. Oleh karena itu ribuan perusahan didirikan orang untuk mengembangkan diri. Perusahaan itu ada yang bertahan dan berhasil, serta ada pula yang mengalami kegagalan. Ada yang berkembang dan berhasil karena perusahaan tersebut dikelola 
oleh wiausahawan yang berpengalaman dan tahu apa yang sedang dilakukannya. Bakat seorang Wirausaha akan bertambah dan berkembang berkat pengetahuan, pengalaman, dan keterampilan yang diperoleh dari hasil interaksi dengan lingkungan.

Kekurangan dan kelemahan yang terdapat pada Wirausaha harus terus menerus dikurangi, ia terus menerus bekerja keras, ia akan berusaha belajar dari sesama profesi, memahami dan mengenal lingkungan yang mampu mengembangkan dirinya serta mengenali profesinya sendiri. Dalam setiap kasus, para pendiri perusahaan haus meraih keberhasilan, mencari pengalaman dan pengetahuan mengenai kewirausahaan. Wirausaha harus berusaha mengenali titiktitik kelemahannya, untuk melakukan tindakan yang positif. Wirausaha memerlukan kebebasan untuk memilih dan bertindak menurut persepsinya sendiri.

Sebagai langkah awal untuk memulai berwirausaha, dapat dilakukan oleh seseorang melalui langkah-langkah yang akan dijelaskan di bawah ini.

\section{Langkah-langkah memulai wirausaha}

Menurut modul pembelajaran wirausaha yang dikeluarkan oleh Dirjen Dikti, ada beberapa langkah-langkah yang dapat dilakukan apabila seseorang ingin memulai wirausaha.

a. Pilih bidang usaha yang Anda minati dan memiliki hasrat dan pengetahuan di dalamnya.

Kewirausahaan (entrepreneurship) muncul apabila seseorang individu berani mengembangkan usaha-usaha dan ide-ide barunya. Proses kewirausahaan meliputi semua fungsi, aktivitas dan tindakan yang berhubungan dengan perolehan peluang dan penciptaan organisasi usaha (Suryana, 2001). Wirausahawan adalah mereka yang melakukan upaya-upaya kreatif dan inovatif dengan jalan mengembangkan ide, dan meramu sumber daya untuk menemukan peluang (opportunity) dan perbaikan (preparation) hidup (Prawirokusumo, 1997)

Tips pertama ini sangatlah membantu bagi seseorang yang cenderung memiliki keinginan yang tinggi sekaligus mudah jenuh. Tidak mudah memang, terutama jika seseorang sudah lama dan terbiasa berada dalam zona aman. Seringkali kesibukan kerja membunuh instink seseorang untuk berkreasi maupun mengasah minat dan kesukaan yang mampu mendatangkan uang. Jika anda telah menentukan minat, maka segeralah asah pengetahuan dan perbanyak bacaan serta ketrampilan mengenai bidang usaha yang hendak Anda tekuni.

Kadang-kadang hal-hal yang dirasakan sudah dikuasai, ternyata setelah berada di lapangan berbeda drastis dengan yang dipikirkan. Seorang yang sehari-hari mengerjakan pekerjaan keahlian tertentu, belum tentu bisa sukses berbisnis dalam bidang tersebut, karenanya perlu sekali belajar dari orang-orang yang telah sukses merintis usaha di bidang tersebut. Belajar dan menimba ilmu dan pengetahuan tersebut dapat dilakukan melalui magang atau kerjasama dengan berbagai pihak yang telah sukses dibidang bisnis.

\section{b. Perluas dan perbanyak jaringan bisnis dan pertemanan.}

Sebagai seorang wirausaha dalam kegiatan usaha memerlukan kerjasama usaha dengan pihak lain, dan dalam memilih mitra kerjasama tentu memilih mitra yang memiliki kelebihan atas kekurangan yang dimiliki diri sendiri, serta memberi manfaat baik bagi diri sendiri maupun mitra kerja sama. Dengan demikian, kerja sama tidak didorong oleh kepentingan sepihak saja, melainkan harus dilandasi oleh kesepakatan yang membawa kemaslahatan kedua pihak. Sebuah langkah penting dimana seseorang mendapatkan informasi dari interaksi dengan orang lain. Beberapa ahli menyarankan ketika seorang takut berwirausaha secara sendirian, maka mengawali usaha secara kelompok adalah alternatif. Oleh karenanya, kualitas dan 
kuantitas dalam interaksi sosial akan lebih memungkinkan individu akan membuat kelompok dalam berwirausaha. Informasi yang penting ketika akan memulai usaha adalah informasi mengenai lokasi, potensi pasar, sumber modal, pekerja, dan cara pengorganisasiannya. Kombinasi antara jaringan yang luas dan kenekaragaman latar belakang akan mempermudah mendapatkan informasi tersebut.

Jaringan dan pertemanan memberikan jalan dalam membangun usaha seseorang, karena Seringkali tawaran-tawaran peluang bisnis dan dukungan pengembangan bisnis datang dari rekan-rekan di dalam jaringan tersebut. Namun anda tetap harus hati-hati, karena tidak pernah ada yang namanya makan siang gratis, siapapun itu, anda harus tetap berhati-hati dan mempersiapkan akan datangnya hal-hal yang tidak terduga. Oleh karena itu, sebelum kesepakatan kerja sama ditandatangani, harus jelas dulu apa saja yang disepakati beserta aturan mainnya dan sanksi-sanksi, bila salah satu pihak ingkar janji dari kerja sama

\section{c. Pilihlah keunikan dan nilai unggul dalam produk/jasa anda.}

Suatu usaha dapat dilakukan yang sesuai dengan keahliannya maupun kemampuan pelayanannya. Seperti counter HP di Semarang merupakan bisnis yang menjamur dalam 3-4 tahun ini. Jika mereka tidak mempunyai keunggulan kompetitif misalnya layanan purna jual, harga yang bersaing, ataukah layanan secara umum baik, maka sulit akan berkembang. Seseorang datang ke sebuah toko untuk membeli HP, sebagian besar karena informasi yang telah didapatkan sebelumnya apakah dari mulut ke mulut ataukah dari koran. Hal ini sangat berbeda dengan ahli terapis untuk anak autis. Kenyataan menunjukkan penderita autis meningkat di masyarakat, sementara layanan atau terapis autis belum terlalu banyak. Keahlian khusus yang 'langka' akan dicari orang tanpa mempertimbangkan aspek lokasi usaha.
Kebanyakan orang tidak sadar, ketika memulai berbisnis, terjebak di dalam fenomena banting harga. Padahal, ada kalanya, harga bukan segalanya. Anda harus bisa mencari

celah dan ceruk pasar yang unik. Anda harus menentukan posisi anda di dalam peta persaingan usaha. Jika anda menilai terlalu tinggi jasa/produk anda, sementara hal yang anda tawarkan itu tidak punya keunggulan yang sangat spesifik dan memiliki nilai tambah, maka orang akan berpaling kepada usaha sejenis dengan harga dan kualitas yang jauh lebih baik.

d. Jaga kredibilitas dan brand image.

Menjaga kredibilitas dan brand image merupakan suatu yang penting dalam memulai usaha. Seringkali kita ketika memulai berusaha, melupakan faktor nama baik, kredibilitas dan pandangan orang terhadap produk/jasa kita.

Menurut Kotler, terdapat lima kualitas layanan yang perlu diperhatikan oleh suatu usaha, agar pelayanan yang diberikan berkualitas, yaitu

1) Reliability (Keandalan), yaitu kemampuan untuk memberikan layanan sesuai dengan yang dijanjikan dengan terpercaya , akurat, dan konsisten.

2) Responsiveness ( Daya Tanggap ), yaitu kemauan untuk membantu pelanggan dan memberikan layanan dengan cepat serta mendengar dan mengatasi keluhan/komplain yang diajukan konsumen.

3) Assurance (Kepastian), yaitu berupa kemampuan untuk menimbulkan keyakinan dan kepercayaan terhadap janji yang telah dikemukakan kepada konsumen.

4) Emphaty (Empati), yaitu kesediaan untuk lebih peduli memberikan perhatian, kesopanan, hubungan personal secara pribadi kepada pelanggan.

5) Tangible (Berwujud), yaitu berupa penampilan fasilitas fisik, peralatan, dan berbagai media komunikasi.

Misalnya salah satu usaha bisnis, seringkali bertindak arogan dan mengabaikan keluhan 
para pelanggannya, padahal bukan hanya sekali dua kali orang-orang melakukan komplain, akibatnya, kehilangan pelanggan adalah hal nyata yang akan terjadi dan bahkan kehilangan pasar potensial dan pangsa pasar yang dikuasainya.

Menurut Aaker \& David (1996:23) menyatakan bahwa untuk meningkatkan kesetiaan pelanggan perusahaan dapat melakukan tiga tindakan. Pertama, melalui frequent buyer program, yaitu usaha untuk memberikan penghargaan dan memperkuat perilaku pembelian ulang, dianggap efektif untuk meningkatkan kesetiaan pelanggan. Kedua, pembentukan customer club, sehingga perusahaan dapat melakukan komunikasi langsung dengan pelanggan dan lebih mengenal dekat siapa pelaggannya, latar belakang, kebutuhan, serta keinginannya, termasuk memperoleh data base pelanggannya. Ketiga, data base marketing, melalui data base marketing yang baik para pelanggan, akan memudahkan bagi perusahaan untuk berkomunikasi tentang produk dan mendapatkan informasi tentang kebutuhan dan keinginan yang "tersembunyi" para pelanggan.

e. Berhemat dalam operasional secara terencana serta sisihkan uang untuk modal kerja dan penambahan investasi alat-alat produksi/jasa.

Menurut Zimmerer (dalam Suryana, 2003 : 44-45) ada beberapa faktor yang menyebabkan wirausaha gagal dalam menjalankan usaha barunya, diantaranya

1) Tidak kompeten dalam manajerial.

Tidak kompeten atau tidak memiliki kemampuan dan pengetahuan mengelola usaha merupakan faktor penyebab utama yang membuat perusahaan kurang berhasil.

2) Kurang berpengalaman baik dalam kemampuan mengkoordinasikan, keterampilan mengelola sumber daya manusia, maupun kemampuan mengintegrasikan operasi perusahaan.

3) Kurang dapat mengendalikan keuangan.
Agar perusahaan dapat berhasil dengan baik, faktor yang paling utama dalam keuangan adalah memelihara aliran kas. Mengatur pengeluaran dan penerimaan secara cermat. Kekeliruan dalam memelihara aliran kas akan menghambat operasional perusahan dan mengakibatkan perusahaan tidak lancar.

Banyak orang yang jika sudah untung besar dan berada di atas, melupakan faktor persiapan akan hal tak terduga maupun merencanakan pengembangan usaha. Padahal bisnis adalah sama dengan hidup, harus selalu bertahan dan berjuang. Banyak pengusaha seperti pengrajin kita, ketika sudah kebanjiran order dan menerima banyak uang, malah mendahulukan membeli mobil mewah ataupun mobil sport. Hal ini tidak salah, namun akan lebih baik jika keuntungan itu disisihkan untuk laba ditahan dan penambahan modal kerja. Dengan demikian usaha bisa lebih berkembang, dan mendapatkan kepercayaan dan pinjaman modal dari bank menjadi lebih mudah.

Sebaiknya untuk keperluan sehari-hari, pemilik perusahaan mencadangkan alokasi dana secukupnya saja untuk biaya hidup dan keperluan pribadi dalam bentuk gaji tetap komisaris/pemilik. Atau disisihkan sebagian saja dari laba tahunan, namun jangan menganggu arus kas perusahaan untuk kepentingan pribadi yang tidak ada urusannya dengan produktivitas usaha.

\section{Kejujuran dalam kewirausahaan}

Sikap positip, seperti kejujuran akan menjadi suatu sikap seorang wirausahawan, apabila sikap jujur itu dilakukan terusmenerus yang diulang, sehingga menjadi suatu kebiasaan. Apabila kita melakukan sikap diluar kebiasaan, maka hati akan merasa gelisah. Kebiasaan-kebiasaan baik susah diperoleh, namun sekali telah diperoleh mereka merupakan harta-harta penting yang sulit dinilai. Salah satu harta kehidupan pada manusia adalah melahirkan 
kebiasaan meraih keberhasilan. Keberhasilan merupakan prestasi, yang dilandasi oleh kejujuran dan disiplin. Seorang Wirausaha yang memiliki keyakinan dan kepribadian, bermula dari adanya ide sendiri, kemudian mengembangkan kegiatan usahanya yang sel alu berpegang pada nilai-nilai kejujuran dan disiplin diri.

Seperti kita ketahui, hidup itu merupakan kancah perjuangan. Karena adanya makna kejujuran dalam hidup, kita harus berjuang dengan penuh keyakinan ingin maju di dalam Wirausaha. Obat yang baik untuk menjalankan perjuangan dalam hidup adalah adanya keyakinan pada diri sendiri. Sayangilah diri sendiri untuk keberhasilan.

Cara pikir positif, kreatif, dan dinamis akan memberikan hasil dalam hidup. Untuk mencapai tujuan yang dicita-citakan, makna kejujuran dan disiplin harus tertanam sejak dini. Kita harus mempelajari dan memahami serta menghayati khasiat kejujuran dalam hidup dan kebenaran dalam arti hidup.

Makna kejujuran dalam hidup ditujukan untuk dunia akhirat sampai tingkat tertentu keberhasilan seorang Wirausaha bergantung kepada kejujuran untuk bertanggung jawab atas pekerjaannya. Jujur dalam berwirausaha artinya mau dan mampu mengatakan sesuatu sebagaimana adanya. Bila berdagang, barang yang baik harus dikatakan baik dan barang yang rusak harus dikatakan rusak. Kejujuran itu dapat disamakan dengan "amanah". Amanah adalah bila diberi kepercayaan dalam berwirausaha tidak khianat, kalau berkata selalu benar dan jika berjanji dalam bisnis tidak mungkir. Makna jujur dalam hidup ini termasuk sifat yang perlu dimiliki oleh seorang Wirausaha, karena sifat ini akan mendatangkan kepercayaan masyarakat konsumen. Dengan kesediaan berbuat jujur, berarti setiap perbuatan yang dilakukan oleh Wirausaha maknanya dapat menyenangkan orang lain maupun diri sendiri.

Akhirnya, dengan ketekunan kerja keras, diikuti dengan kejujuran akan dapat menciptakan suatu kemajuan dalam Wirausaha. Kemajuan yang dicapai tentu harus diikuti dengan disiplin yang baik, bukan sekedar dengan kerja keras ingin hasil yang baik, tapi harus diikuti dengan disiplin tinggi. Kebenaran dan kejujuran adalah suatu jaminan yang paling tepat untuk mencapai kemajuan di dalam wirausaha. Kejujuran dalam segala kegiatan bisnis, misalnya menimbang barang, mengukur, membagi, berjanji membayar utang akan membuat ketenangan lahir dan batin. Memang demikian, berbisnis harus dilandasi oleh kejujuran. Apabila seorang Wirausaha jujur, maka ia akan mendapat keuntungan dari segala penjuru yang tidak ia duga dari mana datangnya. Seorang Wirausaha dapat mengembangkan lingkungannya karena ia dapat memberi apa yang ada, baik tenaga harta maupun pikirannya. Kesediaan berbuat demikian merupakan tingkah laku yang terpuji dan dapat diterima oleh masyarakat. Apabila orang berbisik tidak jujur maka tunggulah kehancurannya.

Ketidakjujuran dalam berusaha dan segala akibatnya, akan membawa kerugian yang sangat fatal. Sifat dan tingkah laku Wirausaha harus dapat menyertai kesabaran, ketekunan, kerajinan, dan kemajuan kerja keras dalam usaha pembinaan pribadi seorang Wirausaha. Seorang Wirausaha yang tidak memiliki kejujuran dan disiplin pribadi tidak akan berhasil di dalam men-capai tujuan dan cita-citanya. Kejujuran dan disiplin pribadi seorang Wirausaha merupakan kewajiban moral yang dibebankan kepada diri sendiri, untuk keperluan diri sendiri menurut fitrahnya. Orang yang tidak jujur di dalam Wirausaha, akan menderita dan akan menerima suatu keadaan:
a. Tidak dipercaya masyarakat konsumen,
b. Menjadi rendah diri dan rasa malu,
c. Mudah tersinggung atau emosi,
d. Cepat iri dan dengki,
e. Suka dendam,
f. Prasangka buruk dan dusta,
g. Tidak punya teman, atau
h. Kehancuran dalam usahanya. 
(Ikaputera Waspada, 2004)

Salah satu kunci keberhasilan seorang Wirausaha di dalam usahanya adalah sifat kejujuran dan kepercayaan dari masyarakat konsumen terhadap dirinya.

Akibat jika seorang Wirausaha di dalam usahanya tidak jujur dan tidak bertanggung jawab adalah banyak masyarakat konsumen yang tidak mempercayainya, baik kepada bidang usahanya maupun kepada kariernya. Hal ini terlebih-lebih kita rasakan pada lapangan kerja di perusahaan dan di perdagangan. Untuk menjadi karyawan pada perusahaan, faktor kejujuran dan tanggung jawab mendapat sorotan dan penilaian yang serius dari pihak pemilik perusahaan. Kejujuran adalah sendi pokok bagi kelangsungan hidup yang diikuti kegiatan pikiran dan kerja keras.

Orang-orang yang selalu ingat kepada Allah di mana pun dan kapan pun adalah orangorang yang jujur, tenang, sabar, serta teratur dalam melaksanakan pekerjaannya. Untuk mencapai kebahagiaan lahir dan batin tidaklah mudah kita ucapkan. Untuk mendapatkannya diperlukan kejujuran dalam perjuangan dan pengorbanan.

\section{Kesimpulan}

Wirausaha adalah kemampuan yang dimiliki oleh seseorang untuk melihat dan menilai kesempatan-kesempatan bisnis; mengumpulkan sumber daya-sumber daya yang dibutuhkan untuk mengambil tindakan yang tepat dan mengambil keuntungan dalam rangka meraih sukses. Memulai usaha merupakan suatu hal yang penting dalam melakukan usaha, oleh sebab itu memerlukan kiat yang tepat untuk memperoleh kesuksesan. Ada beberapa langkah-langkah yang dapat dilakukan apabila seseorang ingin memulai wirausaha, antara lain :

a. Pilih bidang usaha yang Anda minati dan memiliki hasrat dan pengetahuan di

b. dalamnya.

c. Perluas dan perbanyak jaringan bisnis dan pertemanan d. Pilihlah keunikan dan nilai unggul dalam produk/jasa anda

e. Jaga kredibilitas dan brand image

Disamping itu dalam berwirausaha sangat diperlukan kejujuran dalam usahanya, karena akan membawa keberhasilan dan kesuksesan dari akibat kepercayaan pelanggan

\section{DAFTAR PUSTAKA}

Drucker, Peter F, 1996. Inovasi dan Kewirausahaan. Jakartan : Erlangga.

Ikaputera Waspada, 2004. Kiat mengembangkan sikap dan prilaku kerja prestatif. Jakarta : Direktorat Pendidikan Menengah Kejuruan Dirjen Pendidikan Dasar dan Menengah, Departemen Pendidikan nasional.

Ikaputera Waspada, 2004. Kiat mengembangkan sikap jujur dan disiplin. Jakarta : Direktorat Pendidikan Menengah Kejuruan Dirjen Pendidikan Dasar dan Menengah, Departemen Pendidikan nasional.

Ikaputera Waspada, 2004. Kiat mengembangkan ide dan meraih peluang. Jakarta : Direktorat Pendidikan Menengah Kejuruan Dirjen Pendidikan Dasar dan Menengah, Departemen Pendidikan nasional

Kotler Philip, 2000. Manajemen Pemasaran : Analisis,Perencanaan, Implementasi dan Pengendalian.Terjemahan. Jakarata: Erlangga

Suryana, 2003. Kewirausahaan; Pedoman praktis, Kiat dan ProsesMenuju Sukses. Bandung : Salemba Empat.

Suryana,2004. Memahami karakteristik kewirausahaan. Jakarta : Direktorat Pendidikan Menengah Kejuruan Dirjen Pendidikan Dasar dan Menengah, Departemen Pendidikan nasional.

Suryana, 2004. Evaluasi dan pengembangan usaha. Jakarta : 
Direktorat Pendidikan Menengah Kejuruan Dirjen Pendidikan Dasar dan Menengah, Departemen Pendidikan nasional.

Zimmerer W. Thomas Et , 1996.

Entrepreneurship and The New

Venture Formation. New Jersey: prentice Hall Inc. 